\title{
Necrotizing fasciitis of the breast: case report
}

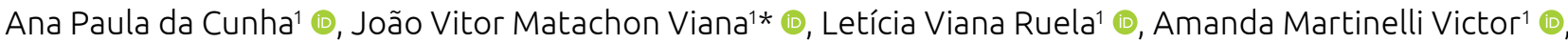

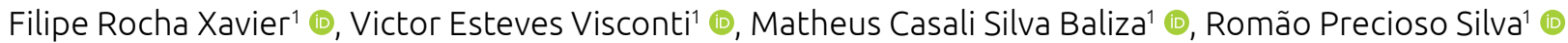

\section{ABSTRACT}

Necrotizing fasciitis is a severe soft tissue infection characterized by rapidly progressive diffuse necrosis of fascia and adjacent tissues, most reported in the abdominal wall, perineum, and extremities. Cases of idiopathic necrotizing fasciitis of the breast are rare and unrelated to risk factors. This study was conducted with a 19-year-old woman reporting mastalgia and phlogistic signs in her right breast, which evolved with serosanguineous blisters and extensive necrosis of the fascia and periareolar wall, characterizing the necrotizing fasciitis. Therefore, the authors aim to show the relevance of early diagnosis associated with prompt treatment and procedure for a better intervention outcome.

KEYWORDS: fasciitis, necrotizing; breast; infections.

\section{INTRODUCTION}

Necrotizing fasciitis (NF) is a severe soft tissue infection characterized by rapidly progressive diffuse necrosis of fascia and adjacent tissues. ${ }^{1}$. Primary NF of the breast without an inciting event is an extremely rare association, with a total of 25 cases found in the literature ${ }^{2}$. Early diagnosis and prompt treatment are essential to reduce the morbidity of $\mathrm{NF}^{1,3}$.

A review of the interdisciplinary electronic databases National Library of Medicine (PubMed), Scientific Electronic Library Online (SciELO), Virtual Health Library (VHL), and Latin American and Caribbean Health Sciences Literature (LILACS) was carried out using the following search terms: "Necrotizing fasciitis," "breast," and "infections," both in Portuguese and English languages.

This descriptive and observational case report, in accordance with the Code of Ethics of the World Medical Association (Declaration of Helsinki) ${ }^{4}$ and the Resolution of the Brazilian Federal Council of Medicine in $1595 / 2000^{5}$, was approved by the Ethics Committee for Research involving Human Beings from Centro Universitário de Volta Redonda upon Certificate of Presentation for Ethical Appreciation(CAAE) 47301421.5.0000.5237, on June 2, 2021.

\section{CASE REPORT}

G.C.R.C., woman, aged 19 years, mixed-race, single, born and resident in the state of Rio de Janeiro (RJ), Brazil. She was admitted to the emergency room (ER) of Hospital São João Batista (HSJB), in the city of Volta Redonda (RJ), on February 22, 2021, reporting mastalgia and phlogistic signs in her right breast for three days, with no preexisting trauma or local wound, associated with fever (without checking the temperature with a thermometer).

The patient is a smoker and denied any history of comorbidities, malignant neoplasms, surgical procedures, or previous gestational history.

On physical examination, she was in regular general condition, with hyperemia of the right breast in the periareolar region, with lateral spread of the inflammatory process. Nipple piercing, implanted two years earlier, was noted, which was removed during the approach.

Upon admission, laboratory tests were requested, whose results showed: $4,000,000 / \mathrm{mm}^{3}$ red blood cells; $10.4 \mathrm{~g} \%$ hemoglobin; $21,200 / \mathrm{mm}^{3}$ leukocytes (1,696 bands, 15,476 polys, 2,756 lymphocytes, 1,272 monocytes); $108,000 / \mathrm{mm}^{3}$ platelets; $102 \mathrm{mg} /$ dL blood glucose; $43 \mathrm{mg} / \mathrm{dL}$ urea; $0.8 \mathrm{mg} / \mathrm{dL}$ creatinine; $46.9 \mathrm{mg} /$ dL C-reactive protein (CRP). After laboratory analysis, under the diagnostic hypothesis of cellulitis, the patient was discharged with prescription of oral amoxicillin and analgesics.

On February 24, two days after being seen at the ER, the patient returned to the unit and was admitted to the Department of Gynecology and Obstetrics (GO). The course of treatment was based on the request for breast ultrasound, the suspension of amoxicillin, the prescription of oxacillin and symptomatic treatment.

'Escola de Ciências Médicas de Volta Redonda, Centro Universitário de Volta Redonda - Volta Redonda (RJ), Brazil.

*Corresponding author: joaomatachon@gmail.com

Conflict of interests: nothing to declare.

Received on: 07/19/2021. Accepted on: 10/08/2021. 
Four hours after admission, the patient developed with periareolar ecchymosis, serosanguineous blisters, and periareolar necrosis (Figure 1). Thus, considering the rapid evolution, the diagnostic hypothesis of NF with extensive cellulitis was established.

On the day after admission, a breast ultrasound was performed, which showed heterogeneous glandular breast parenchyma with edema in the lower and upper lateral quadrants. The presence of axillary lymphadenopathy in the right side was also verified.

Metronidazole was promptly introduced to the therapeutic regimen, maintaining oxacillin, symptomatic treatment, and hospital surveillance. Upon evaluation, there was worsening of the ecchymosis and phlogistic signs. Tests requested during the day showed thrombocytopenia with the need for platelet transfusion, which was subsequently performed. In addition, a decrease in the number of leukocytes and an increase in CRP were identified.

An opinion was requested from the Department of Internal Medicine, which, together with the GO department, started monitoring the young woman. Such departments, isochronally, opted for suspending the use of oxacillin and metronidazole and began to administer teicoplanin and cefepime.

On the third day, the patient underwent surgical debridement with fasciotomy and removal of necrotic tissue (Figure 2). Prior to surgery, cefazolin was administered to the patient, in addition to performing skin asepsis and antisepsis. The operation was uneventful and allowed collecting serum from inside the blisters, which was directed to culture, histopathology, and cytology tests.

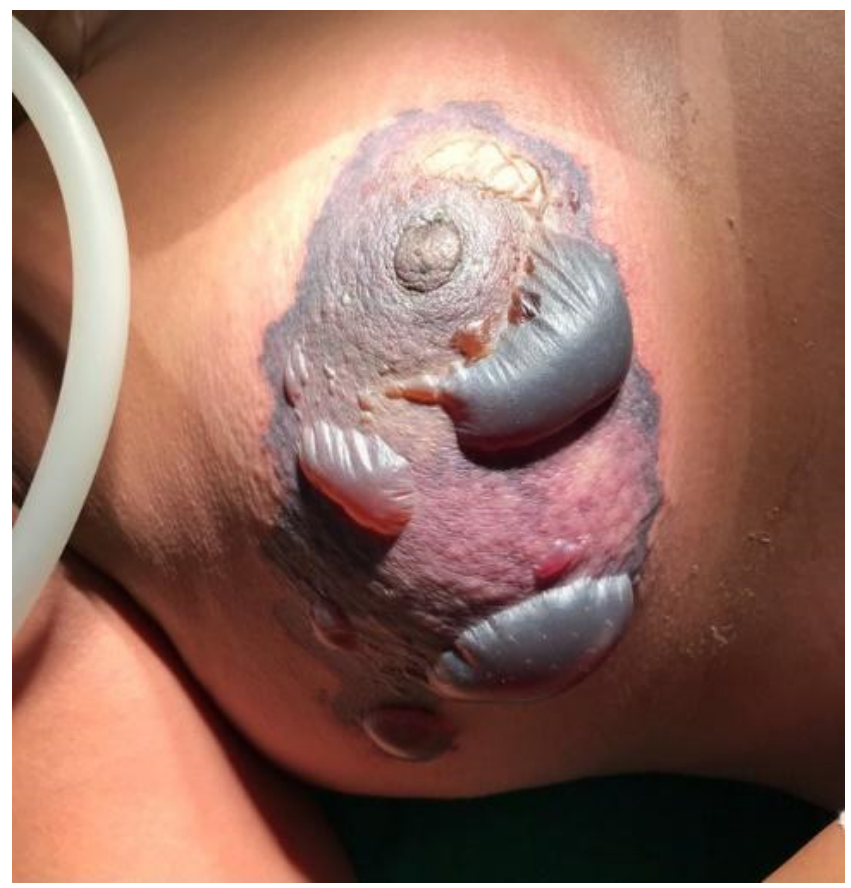

Source: HSJB medical team.

Figure 1. Department of Gynecology and Obstetrics on February 24, 2021, at the time of immediate preoperative, blisters can be noted.
Following debridement, upon presenting with hypotension, altered level of consciousness, and signs of skin sepsis, the patient was referred to the Intensive Care Unit (ICU). In the ICU, antibiotic therapy with clindamycin was introduced and the daily change of the wound dressing based on silver sulfadiazine was recommended. The patient required contact precautions after verifying colonization by extended-spectrum beta-lactamase(ESBL), Klebsiella pneumoniae Carbapenemase (KPC), and Vancomycin-resistant enterococci (VRE) by rectal swab. She remained in the ICU for seven days and, after the septic condition had improved, she was discharged to the GO ward.

No bacterial growth was found in the culture, and the anatomopathological examination of the fascia confirmed an acute suppurative inflammatory process, with necrosis and hemorrhage.

In the ward, the patient received antibiotic therapy for 14 days. The clinical condition evidenced progressive involution with reduced seropurulent secretions and inflammatory signs. At the end of the antimicrobial therapy, the patient was discharged from the hospital and kept under outpatient follow-up.

On April 12, she underwent reconstructive plastic surgery. A skin graft was performed with the infraumbilical region as the donor site. The procedure was uneventful (Figure 3).

\section{DISCUSSION}

$\mathrm{NF}$ is a rare ( 0.4 cases in 100,000 individuals), aggressive infection with high mortality rates ${ }^{6}$. Predisposing conditions include: chronic or immunosuppressive diseases, alcohol abuse, surgeries, penetrating and closed skin wounds and trauma, or even a minimal skin injury ${ }^{7,8}$.

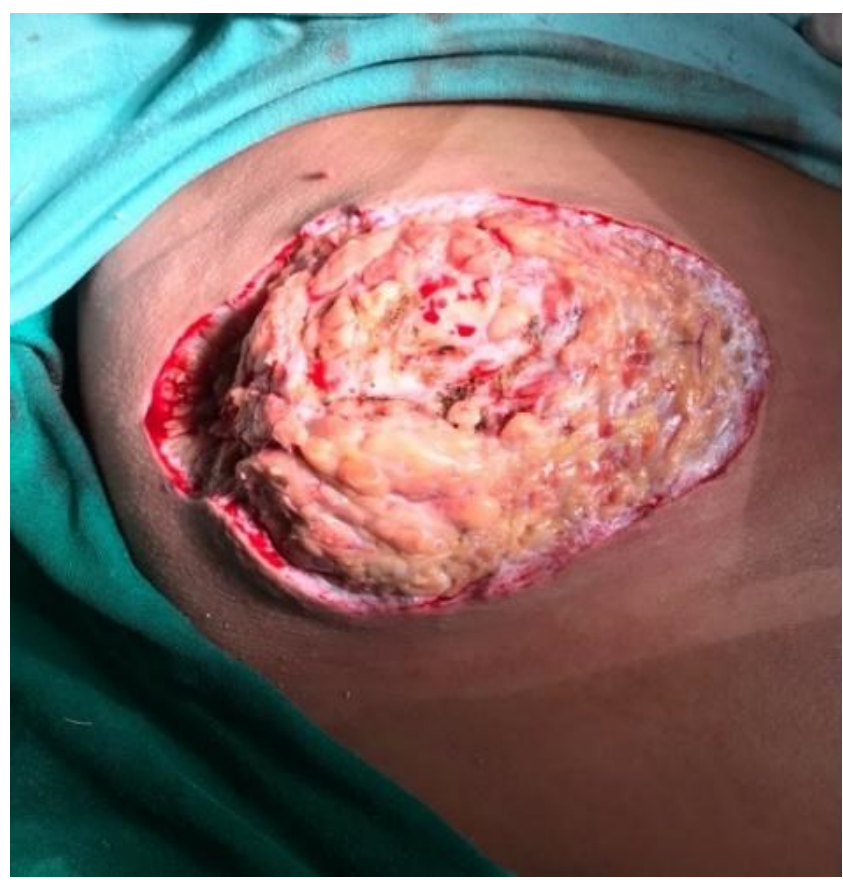

Source: HSJB medical team.

Figure 2. Operating Room on February 27, 2021, at the time of postoperative debridement. 
Streptococcus pyogenes and Staphylococcus aureus, alone or in association, usually are the etiological agents ${ }^{2,9}$.

Acute necrotizing inflammation affects the subcutaneous tissue and fascia. More superficial tissues and skin are secondarily affected, subsequent to vascular trauma, thrombosis, and ischemia ${ }^{3}$.

NF clinically manifests as an erythematous, painful, and localized area correlated with edema, evolving with local cyanosis and blister formation. The impaired area becomes delimited, surrounded by erythematous borders and lined with necrotic tissue. Then, it progresses with the destruction of the underlying subcutaneous tissues and with thrombosis, resulting in necrosis. The lack of treatment can increase the secondary involvement of the muscle layer, even causing myositis or myonecrosis ${ }^{8}$.

Diagnosis is based on clinical findings, corroborated by surgical ones, which include insufficient adherence of the subcutaneous tissue, no bleeding, and subcutaneous liquefactive necrosis. Moreover, serum laboratory abnormalities may support the diagnostic hypothesis, such as: anemia; leukocytosis with left shift; elevated CRP, erythrocyte sedimentation rate (ESR), and creatine phosphokinase (CPK); and hyperglycemia ${ }^{3}$.

Blood cultures and cultures can aid in the identification of microorganisms and sensitivity to antibiotics. Imaging methods can provide additional considerations. Fascia biopsy is considered

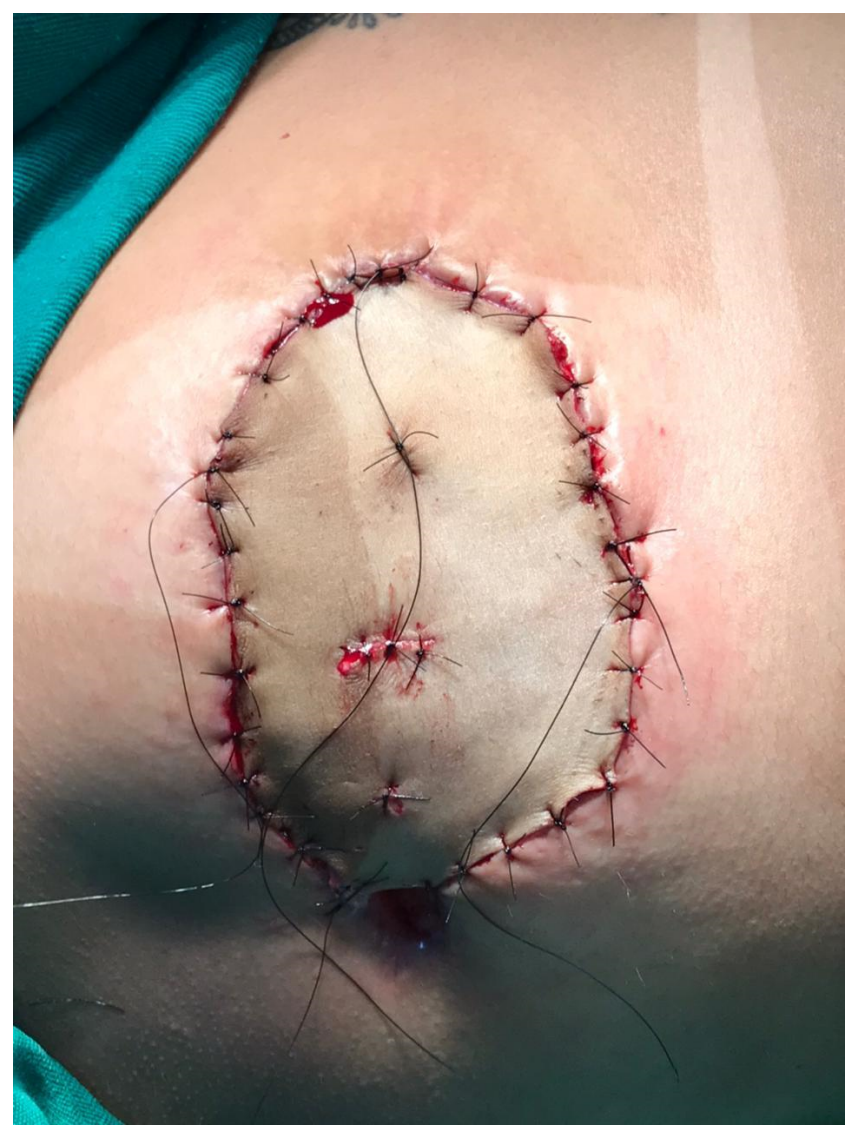

Source: HSJB medical team.

Figure 3. Operating Room on April 12, 2021; the result of breast reconstruction with a skin graft can be observed. the gold standard and should be performed in all patients during debridement ${ }^{3}$.

NF is a surgical emergency, in such a way early diagnosis and prompt treatment are essential to reduce morbidity ${ }^{1}$. Once the diagnosis is made, treatment must immediately starts and include: volume replacement, surgical debridement, use of broad-spectrum antibiotic therapy, and psychological support ${ }^{3}$. After surgical treatment and definition of tissue integrity, skin reconstruction and skin grafts should be scheduled ${ }^{10}$.

The patient of the present report developed NF unrelated to risk factors. Thus, although it can occur in any anatomical site, breast involvement is extremely rare. It was first described in the literature by Shah et al. ${ }^{11}$ and there are about 20 reports of primary breast infection occurring in previously healthy non-lactating women.

Considering the rarity of the pathology and the diagnostic difficulty, the diagnosis is usually late and results in an unusual management plan, with uncontrolled and severe progression of the disease ${ }^{12}$.

The authors ratify the importance of early diagnosis and prompt therapy for an adequate outcome. It is essential to exclude differential diagnoses, considering that the severity and speed of progression, with evolution time inversely proportional to survival rates, justifies the use of broad-spectrum antibiotic therapy, surgical debridement, and support in ICU to avoid complications and eventual lethality ${ }^{6}$.

\section{CONCLUSION}

This report, according to the literature, presents one of the youngest patients to develop primary idiopathic necrotizing fasciitis of the breast. Thus, it describes a rare, serious, and uncommon case of infection in a previously healthy young woman. Therefore, even in healthy patients and in the absence of associated risk factors, NF can present itself as a rapidly progressive and destructive condition. Considering the aggressive nature of the disease, resulting from the difficult and challenging clinical suspicion, early diagnosis and rapid and appropriate intervention are essential to reduce its morbidity and mortality.

\section{AUTHORS' CONTRIBUTIONS}

A.P.C.: Conceptualization, Investigation, Project administration, Supervision, Validation.

R.P.S.: Investigation, Project administration, Supervision, Validation.

J.V.M.V.: Methodology, Research, Writing - original draft, Writing - review \& editing.

A.M.V.: Research, Writing - review \& editing.

F.R.X.: Writing - review \& editing.

L.V.R.: Writing - review \& editing.

M.C.S.B.: Writing - review \& editing.

V.E.V.: Writing - review \& editing. 


\section{REFERENCES}

1. Bravo Neto GP. Fascite necrotizante. In: Tavares W, Marinho LAC, editors. Rotinas de diagnóstico e tratamento das doenças infecciosas e parasitárias. $4^{\mathrm{a}}$ ed. São Paulo: Atheneu; 2015.p. 445-50.

2. KonikRD,HuangGS.Management of primarynecrotizing fasciitis of the breast:a systematic review.PlastSurg(Oakv).2020;28(4):21521. https://doi.org/10.1177/2292550320928557

3. Soares TH,PennaJTM,PennaLG,MachadoJA,AndradeIF,Almeida RC, et al. Diagnóstico e tratamento da fasciíte necrotizante: relato de dois casos. Rev Méd Minas Gerais. 2008;18(2):136-40.

4. Associação Médica Mundial (WMA). Declaração de Helsinque: princípios éticos para pesquisa médica envolvendo seres humanos, de junho de 1964. Adotada pela $18^{a}$ Assembleia Geral da WMA, Helsinque, Finlândia. 64ª Assembleia Geral da WMA; 2013.

5. Conselho Federal de Medicina (CFM). Resolução CFM $\mathrm{n}^{\circ} 1.595 / 2000$, de 18 de maio de 2000. Dispõe no uso das atribuições conferidas pela Lei $\mathrm{n}^{\circ} 3.268$, de setembro de 1957 , regulamentada pelo Decreto no 44.045, de 19 de julho de 1958 . Diário Oficial da União. 2000;Seção 1:18.

6. Maldonato GC, Barbalho DM, Salum FCA, Vita MIC, Belem RF, Vogt MFB. Necrotizing fasciitis of breast in postpartum period: case report. Mastology. 2018;28(2):110-3. https://doi.or g/10.29289/2594539420180000348
7. Taviloglu K, Yanar H. Necrotizing fasciitis: strategies for diagnosis and management. World J Emerg Surg. 2007;2:19. https://doi.org/10.1186/1749-7922-2-19

8. Costa IMC, Cabral ALSV, Pontes SS, Amorim JF. Fasciíte necrosante: revisão com enfoque nos aspectos dermatológicos. An Bras Dermatol. 2004;79(2):211-24. https://doi.org/10.1590/ S0365-05962004000200010

9. Kwak YG, Choi SH, Kim T, Park SY, Seo SH, Kim MB, et al. Clinical guidelines for the antibiotic treatment for communityacquired skin and soft tissue infection. Infect Chemother. 2017;49(4):301-25. https://doi.org/10.3947/ic.2017.49.4.301

10. Santos AA, Silva FCL, Souza KRF, Póvoas FTX, Bastos MLA, Lúcio IML. Assistência de enfermagem a puérpera com fasceíte necrotizante: relato de experiência. Rev Enferm UFPE On Line. 2013;7(4):1248-53. https://doi.org/10.5205/reuol.318826334-1-LE.070401323

11. Shah J, Sharma AK, O’Donoghue JM, Mearns B, Johri A, Thomas V. Necrotising fasciitis of the breast. Br J Plast Surg. 2001;54:67-79. https://doi.org/10.1054/bjps.2000.3461

12. Marks B, Fasih T, Amonkar S, Pervaz M. Necrotising fasciitis of the breast: a rare but deadly disease. Int J Surg Case Rep. 2019;65:10-4. https://doi.org/10.1016/j.ijscr.2019.10.020 